\title{
PENERAPAN E-CUSTOMER RELATIONSHIP MANAGEMENT PADA TAMAN KANAK-KANAK HANIFA
}

\author{
Dina Chairuna; Yuliana Lisanti; Engkos Achmad Kuncoro \\ Information Systems Department, School of Information Systems, Binus University \\ Jln. K.H. Syahdan No. 9, Palmerah, Jakarta Barat 11480 \\ dinachairuna@yahoo.com; Lisanti@binus.edu; eak@binus.edu
}

\begin{abstract}
Maintaining relationships with customers is an important factor to be the key to success of Hanifa kindergarten as a pre-school institution. It requires a precise strategy to be executed and a system to support the strategy. The design method begins with several analyses on the running business processes and the external and internal factors that affect the school. The analyses are then followed by a SWOT Matrix and Internal-External Matrix which produce several alternative strategies to be implemented. The strategy formulation results in a website-based application of E-Customer Relationship Management (E-CRM) with features including three phases in Customer Relationship Management, which are acquire phase, enhance phase and retain phase. The analysis and system design is conducted using object-oriented analysis and design (OOA \& D) as documented by notation Unified Modeling Language (UML).
\end{abstract}

Keywords: analysis, design, strategy, e-CRM, OOAD, UML

\begin{abstract}
ABSTRAK
Menjaga hubungan dengan para pelanggan merupakan faktor penting yang akan menjadi kunci sukses TK Hanifa sebagai institusi pendidikan anak usia prasekolah. Untuk mencapai hal tersebut diperlukan suatu strategi tepat bagi TK Hanifa sistem yang mendukung strategi tersebut. Metode perancangan dimulai dari tahapan analisis terhadap proses bisnis berjalan, analisis terhadap faktor eksternal dan internal yang berpengaruh terhadap sekolah. Analisis tersebut kemudian ditindaklanjuti dengan Matriks SWOT dan Matriks Internal-Eksternal yang menghasilkan beberapa strategi alternatif yang dapat diimplementasikan. Hasil yang diperoleh dari perumusan strategi adalah pembuatan aplikasi E-Customer Relationship Management (E-CRM) berbasis website dengan fitur-fitur yang mencakup tiga fase dalam Customer Relationship Management yaitu fase acquire, fase enhance, dan fase retain. Analisis dan perancangan sistem dilakukan menggunakan metode object-oriented analysis and design (OOA\&D) yang didokumentasikan dengan notasi Unified Modelling Language (UML).
\end{abstract}

Kata kunci: analisis, perancangan, strategi, e-CRM, OOAD, UML 


\section{PENDAHULUAN}

Bagi Taman Kanak-Kanak (TK) Hanifa, informasi mengenai perkembangan anak merupakan hal yang sangat penting baik pihak sekolah maupun orang tua murid. Berdasarkan wawancara singkat dengan salah satu orang tua murid, berbagi informasi mengenai perkembangan anak di sekolah memberikan rasa aman bagi orang tua atas pendidikan yang diberikan oleh TK Hanifa terhadap anaknya. Begitu pula sebaliknya, informasi mengenai perkembangan anak dirumah juga membantu pihak sekolah untuk memantau perkembangan anak di lingkungan luar sekolah.

"Penyampaian informasi yang selama ini berjalan di TK Hanifa masih bersifat manual dengan menggunakan buku penghubung antara orang tua dan guru, sehingga memiliki berbagai kendala seperti informasi yang disampaikan tidak up-to-date, dan informasi mengenai pendidikan anak yang seharusnya disampaikan antar pendidikan di sekolah dan di rumah oleh orang tua dan guru juga tidak berjalan dengan baik", ungkap Soetarlina Sukadji. Internet sebagai media komunikasi dan informasi memberikan kemudahan dalam menyebarkan dan menerima informasi secara cepat dengan jangkauan yang luas. Dengan tetap terjalin komunikasi yang baik, TK Hanifa dapat mengetahui dengan lebih baik keinginan dan harapan dari para murid dan orang tua. Untuk membantu melakukan pemasaran dan membina hubungan baik dengan pelanggan perusahaan, dalam kasus ini adalah para murid dan orang tua, TK Hanifa dapat menerapkan e-CRM (electronic Customer Relationship Management).

Menurut Kotler \& Keller (2004, p.16) Customer relationship management adalah keseluruhan proses dalam membangun dan memelihara hubungan pelanggan yang menguntungkan dengan memberikan nilai dan kepuasan pelanggan. CRM digunakan untuk mengatur informasi detil mengenai pelanggan secara individual dan secara teliti mengatur hubungan dengan pelanggan yang bertujuan memaksimalkan kepuasan pelanggan. E-CRM merujuk pada manajemen hubungan pelanggan secara elektronik atau lebih sederhananya adalah CRM berbasiskan web (Dyche, 2002, p.12). Menurut Turban et al., (2008, p.607) E-Customer Relationship Management adalah Customer Relationship Management yang di lakukan secara elektronik. Keuntungan CRM menurut Turban et al., (2008, p.608) adalah membuat pelanggan senang dengan menyediakan pilihan atas produk dan jasa yang diberikan, pemecahan masalah dan respon yang cepat, akses yang mudah dan cepat terhadap informasi. Menurut. Namun, tujuan utama CRM bukan mempertahankan pelanggan yang akan berubah menjadi kompetitor melainkan untuk sederhananya melayani pelanggan, tujuan utamanya adalah untuk mengidentifikasi, memelihara, dan mempertahankan pelanggan yang tepat untuk memicu penggunaan yang berulang atas produk atau jasa yang dihasilkan oleh perusahaan (Baran et al., 2008, p.10).

E-CRM menggunakan internet dengan membuat website yang dapat diakses oleh pelanggan dari berbagai waktu dan tempat guna meningkatkan kepuasan pelanggan, loyalitas pelanggan dan keunggulan kompetitif dari perusahaan dimana akan dibangun pengetahuan mengenai pelanggan yang bersifat individual yang secara tidak langsung menstimulasikan strategi marketing dari perusahaan.

\section{METODE}

Sebelum melakukan perumusan strategi yang tepat untuk Customer Relationship Management TK Hanifa, perlu dilakukan analisis terhadap proses bisnis berjalan, analisis terhadap faktor eksternal dan internal yang berpengaruh terhadap sekolah. Analisis tersebut kemudian ditindaklanjuti dengan Matriks SWOT dan Matriks Internal-Eksternal yang menghasilkan beberapa strategi alternatif yang dapat diimplementasikan. Hasil yang diperoleh dari perumusan strategi adalah pembuatan aplikasi E-customer Relationship management (E-CRM) berbasis website dengan fitur-fitur yang mencakup tiga fase, yaitu fase acquire, fase enhance, dan fase retain. Analisis dan perancangan sistem dilakukan 
menggunakan metode object-oriented analysis and design (OOA\&D) yang didokumentasikan dengan notasi Unified Modelling Language (UML).

\section{HASIL DAN PEMBAHASAN}

Dalam melakukan perumusan strategi yang komprehensif terdapat tiga tahap yang ada dalam kerangka pengambilan keputusan. Tahap pertama adalah tahap input yang berisi informasi dasar yang dibutuhkan dalam merumuskan strategi. Tahap ini pada dasarnya tidak hanya sekedar kegiatan pengumpulan data melainkan suatu kegiatan pengklasifikasian dan pra-analisis. Pada tahap ini data dapat dibedakan menjadi dua yaitu data internal dan data eksternal. Tahap kedua adalah tahap pencocokan yaitu tahap yang fokus pada penciptaan strategi-strategi alternatif yang berasal dari informasi internal dan eksternal yang diperoleh dari tahap sebelumnya. Tahap ketiga yang merupakan tahap terakhir adalah tahap keputusan yang hanya melibatkan satu teknik yaitu menggunakan informasi input dari tahap pertama untuk secara objektif melakukan evaluasi atas strategi-strategi alternatif yang diperoleh dari tahap pencocokan.

\section{Analisis Lingkungan Internal}

\section{Fungsi Manajemen}

Keuangan - belum stabil karena biaya operasional yang cukup tinggi memiliki dampak pada pendapatan dari Yayasan Hanifa. Dengan menggunakan metode BCCT (Beyond Center Circle Time) atau moving class diperlukan tenaga pengajar yang lebih banyak dibandingkan metode konvensional. Selain itu, alat dan bahan yang digunakan juga lebih banyak dan beragam sehingga menaikkan biaya operasional yang dibutuhkan. Biaya operasional sendiri mencapai 78 persen dari total pendapatan TK Hanifa yang berasal dari uang pangkal gedung, uang pendidikan, dan uang SPP. Untuk kesejahteraan karyawan, Yayasan Hanifa memiliki kebijakan khusus yaitu memberikan kebebasan biaya bagi guru yang telah bekerja sekurang-kurangnya satu tahun yang ingin menyekolahkan anak pertama dan keduanya di TK Hanifa. Bagi yang memiliki anak pada usia Kelompok Bermain maka akan dibebaskan uang pangkal, uang gedung, formulir, dan membayar iuran SPP 50 persen dan Seragam. Sedangkan untuk usia TK hanya membayar uang seragam dan uang komite. Pendapatan Karyawan saat ini mengalami peningkatan sebesar 14 persen.

Pemasaran - mengikuti pameran-pameran pendidikan yang diadakan di daerah Pamulang dan sekitarnya dengan memberikan penjelasan mengenai metode pembelajaran yang dimiliki oleh TK Hanifa sebagai keunggulan atau daya saing TK Hanifa dengan Taman kanak-kanak lainnya. Serta memberikan informasi mengenai fasilitas-fasilitas dan pelayanan yang dimiliki. TK Hanifa juga melakukan pemasaran dengan memasang spanduk TK Hanifa dan memasang iklan di Koran kota pamulang. Pemasaran juga berlangsung dengan cara word of mouth melalui para alumni TK Hanifa maupun orang tua murid yang menyekolahkan anaknya di TK Hanifa. Lokasi yang cukup strategis yaitu berada di jalan pamulang raya yang merupakan jalan utama di kota pamulang yang letaknya sejajar dengan kantor walikota Tangerang serta sejajar dengan bangunan pamulang town square, menjadi modal utama bagi TK Hanifa sebagai salah satu alat pemasarannya. Pemasaran yang ada hanya melalui media cetak, dan keikutsertaan dengan pameran-pameran pendidikan, belum ada pemasaran yang menggunakan fasilitas internet.

Sistem informasi - dibangun oleh IT and Software Development Smart Solution menggunakan Microsoft Visual FoxPro. Modul yang ada antara lain adalah modul untuk data murid, data orang tua, data guru, data pembayaran anak, data persediaan seragam anak dan kegiatan operasional sekolah. Selain itu TK Hanifa juga bekerja sama dengan Smart Solution untuk membangun sistem keuangan 
yang memiliki modul-modul pengelolaan transaksi harian kas dan bank, pengelolaan utang/piutang dan pengelolaan cek dan bilyet giro. Laporan yang dihasilkan oleh modul-modul tersebut antara lain laporan transaksi harian, laporan jurnal harian dan jurnal penyesuaian, laporan buku kas dan buku bank, serta laporan yang berbentuk trend dari hasil laporan yang ada untuk keperluan pengambilan keputusan oleh Yayasan Hanifa. Sedangkan untuk laporan mengenai perkembangan anak peserta didik di TK Hanifa masih menggunakan cara manual dan terbatas pada laporan yang diberikan yaitu menggunakan buku penghubung, laporan portofolio dan buku raport, untuk mengetahui penjelasan maka orang tua dapat mendatangi sekolah untuk informasi lebih lanjut. Di TK Hanifa belum tersedia sebuah aplikasi atau media yang menunjang untuk mengetahui kebutuhan orang tua murid.

Sumber daya manusia - tenaga pengajar terdiri dari guru-guru yang memiliki pendidikan PGTK (Pendidikan Guru Taman Kanak-Kanak) maupun dari PGTKI (Pendidikan Guru Taman Kanak-Kanak Islam) serta terdapat 50 persen guru yang memiliki gelar Strata 1 (satu). Guru yang lainnya sedang dalam proses penyelesaian program strata 1 (satu) sehingga tahun depan semua guru akan memiliki gelar strata 1 (satu). TK Hanifa juga terdaftar dalam IGTKI (Ikatan Guru Taman Kanak-Kanak Indonesia).

\section{Resource-Based View}

Sumber daya fisik (aset berwujud atau tangible asset) - lokasi yang cukup strategis, yaitu berada di pinggir jalan pamulang raya yang telah mengalami pelebaran jalan sehingga menjadi empat jalur dua arah dan merupakan jalan utama di daerah pamulang. Bangunan TK Hanifa berdiri di lahan seluas $1.350 \mathrm{~m} 2$ yang memberikan keleluasaan bagi murid-murid untuk menikmati berbagai fasilitas yang dimiliki oleh TK Hanifa dimulai dari kolam renang, aula pertunjukan, studio musik, area bermain dan berbagai fasilitas lainnya yang menunjang kegiatan belajar mengajar di TK Hanifa.

Sumber daya manusia (aset tak berwujud/intangible asset) - tenaga pengajar di TK Hanifa rata-rata memiliki pendidikan yang baik yaitu hampir separuhnya adalah lulusan Strata satu, sisanya adalah lulusan dari PGTK (Pendidikan Guru Taman Kanak-Kanak) maupun dari PGTKI (pendidikan guru taman Kanak-kanak Islam) jumlah karyawan yang dimiliki adalah sebanyak dua puluh empat karyawan. Keahlian yang dimiliki oleh tenaga pengajar TK Hanifa selalu ditingkatkan melalui berbagai training atau pelatihan yang diikuti oleh guru-guru secara berkala dan bergantian. Sedangkan prestasi yang dimiliki oleh guru-guru TK Hanifa sangat memuaskan dimulai dari prestasi kreativitas guru hingga prestasi guru teladan tingkat nasional.

Sumber daya organisasional (kapabilitas organisasional/organizational capabilities) - metode yang dijalankan oleh TK Hanifa menjadikan guru hanya sebagai fasilitator dalam proses pembelajaran, yaitu anak akan diberikan penjelasan mengenai tema yang akan dipelajari pada hari itu kemudian memberikan kebebasan bagi anak untuk mengembangkan kreativitasnya tanpa ada arahan khusus dari gurunya yang bertujuan untuk menggali potensi yang dimiliki oleh anak didik dan mendorong anak didik membuat hubungan antara pengetahuan, pengalaman, dan penerapan dalam kehidupan mereka sehari-hari. Sehingga otak anak dirangsang untuk terus berfikir secara aktif dalam menggali pengalamannya sendiri bukan sekedar mencontoh dan menghafal saja. Yayasan Hanifa baru memiliki satu tingkatan sekolah yaitu tingkatan pendidikan prasekolah. Standar penerapan bahasa di TK Hanifa masih dalam bilingual, yaitu Bahasa Indonesia dan Bahasa Inggris. Dengan informasi-informasi di atas dapat diidentifikasikan kekuatan dan kelemahan yang dimiliki oleh TK Hanifa (Tabel 1).

Tabel 1

Kekuatan (Strength) Dan Kelemahan (Weakness) TK Hanifa

\begin{tabular}{cl}
\hline Strength \\
\hline S1 & Memiliki lokasi yang strategis yang berada di pusat kota tangerang selatan \\
S2 & Memiliki tenaga pengajar yang $50 \%$ strata 1 serta berprestai
\end{tabular}


S3 Pendapatan karyawan meningkat $14 \%$

S4 Telah menjalankan Metode pembelajaran BCCT Sepenuhnya selama 6 tahun

S5 Telah melakukan investasi dalam pengembangan sistem informasi

\section{Weakness}

W1 Tidak memiliki tingkatan sekolah dasar

W2 TK Hanifa belum memiliki standar internasional

W3 Penyediaan pelayanan informasi lambat dan terbatas

W4 Pemasaran terbatas pada media cetak dan keikutsertaan dalam pameran

W5 Belum tersedia sebuah aplikasi atau media yang menunjang untuk mengetahui

kebutuhan orang tua murid

\section{Matriks Evaluasi Faktor Internal}

Merupakan alat perumusan strategi yang meringkas dan mengevaluasi kekuatan dan kelemahan suatu perusahaan. Tabel 2 berikut menunjukkan matriks evaluasi faktor internal TK Hanifa.

Tabel 2

Matriks Evaluasi Faktor Internal TK Hanifa

\begin{tabular}{|c|c|c|c|c|}
\hline \multicolumn{2}{|c|}{ Strength } & \multirow{2}{*}{\begin{tabular}{|l|} 
Bobot \\
0,0497
\end{tabular}} & \multirow{2}{*}{$\begin{array}{c}\text { Rank } \\
4\end{array}$} & \multirow{2}{*}{\begin{tabular}{|c|}
$\begin{array}{c}\text { Skor } \\
\text { Bobot }\end{array}$ \\
0,1988 \\
\end{tabular}} \\
\hline S1 & $\begin{array}{l}\text { Memiliki lokasi yang strategis yang berada di pusat kota } \\
\text { tangerang selatan }\end{array}$ & & & \\
\hline S2 & Memiliki tenaga pengajar yang $50 \%$ strata 1 serta berprestai & 0,0757 & 3 & 0,2271 \\
\hline S3 & Pendapatan karyawan meningkat $14 \%$ & 0,0246 & 3 & 0,0738 \\
\hline S4 & $\begin{array}{l}\text { Menjalankan Metode pembelajaran BCCT Sepenuhnya selama } \\
6 \text { tahun }\end{array}$ & 0,2013 & 4 & 0.8052 \\
\hline S5 & Melakukan investasi dalam pengembangan sistem informasi & 0,1797 & 3 & 0,5391 \\
\hline \multicolumn{5}{|c|}{ Weakness } \\
\hline W1 & Tidak memiliki tingkatan sekolah dasar & 0,0333 & 2 & 0,0666 \\
\hline W2 & belum memiliki standar internasional & 0,0255 & 1 & 0,0255 \\
\hline W3 & Penyediaan pelayanan informasi lambat dan terbatas & 0,1637 & 2 & 0,3274 \\
\hline W4 & $\begin{array}{l}\text { Pemasaran terbatas pada media cetak dan keikutsertaan dalam } \\
\text { pameran }\end{array}$ & 0,1334 & 2 & 0,2668 \\
\hline \multirow[t]{2}{*}{ W5 } & $\begin{array}{l}\text { Belum tersedia aplikasi atau media yang menunjang untuk } \\
\text { mengetahui kebutuhan orang tua murid }\end{array}$ & 0,1131 & 1 & 0,1131 \\
\hline & TOTAL & 1 & & 2,6434 \\
\hline
\end{tabular}

Skor bobot sebesar 2,6434 yang berarti berada di atas rata-rata (titik tengah 2,5), yang mengindikasikan adanya kesempatan baik dalam melakukan perbaikan dalam hal keuangan, sistem informasi, layanan, serta metode pembelajaran di TK Hanifa.

\section{Analisis Lingkungan Eksternal}

Analisis lingkungan eksternal mengacu kepada kejadian atau trend diluar organisasi yang berada diluar kendali organisasi. Kejadian atau trend tersebut memiliki pengaruh terhadap berlangsungnya organisasi dalam menjalankan bisnisnya.

\section{PEST Analysis}

Faktor politik, hukum, dan pemerintah - suatu lembaga pendidikan jika ingin tetap diakui keberadaannya secara fungsional di tengah-tengah arus kehidupan yang semakin kompetitif seperti sekarang ini harus didukung oleh ketiga hal yaitu sumber daya manusia, manajemen dan dana. Berbagai 
kelemahan tersebut paling tidak merupakan persoalan yang harus dijawab oleh sistem dan kebijakan pendidikan di Indonesia saat ini. Hal ini karena pendidikan memegang amanat tertinggi bangsa ini sebagai sarana untuk membina dan membangun manusia seutuhnya, sebagaimana tercermin dalam Pembukaan Undang-Undang Dasar 1945, "untuk memajukan kesejahteraan umum dan mencerdaskan kehidupan bangsa”.

Faktor ekonomi - keadaaan ekonomi memiliki pengaruh yang signifikan bagi keberlangsungan TK Hanifa, mulai dari tingkat pendapatan dan tingginya pengangguran yang akan mempengaruhi kecenderungan orang tua untuk memasukkan anaknya ke lembaga pendidikan taman kanak-kanak. Berdasarkan data dari pemerintah Tangerang Selatan, Produk Domestik Regional Bruto (PDRB) atas dasar harga berlaku Kota Tangerang Selatan pada tahun 2007 adalah sebesar Rp.5.256.882,05 Juta, sedangkan PDRB atas dasar harga konstan adalah sebesar Rp.2.768.787,17 Juta. Dengan jumlah penduduk pertengahan tahun 2007 mencapai 1.042.682 orang, PDRB per kapita adalah sebesar Rp.5,042 Juta. Perkembangan PDRB Kota Tangerang Selatan cenderung menunjukkan peningkatan dari tahun ke tahun demikian juga dengan PDRB per kapita. Pada tahun 2007, laju pertumbuhan ekonomi (LPE) adalah sebesar 6,51\%. Pada tahun 2003, PDRB per kapita atas dasar harga konstan adalah sebesar Rp.863.517 sedangkan pada tahun 2007 adalah sebesar Rp.1.042.682. Dengan semakin besarnya pendapatan orang akan cenderung memberikan pengeluaran yang lebih besar untuk pendidikan. Namun di sisi lain pertumbuhan ekonomi dapat dikatakan tidak stabil dikarenakan Menurut Bank Indonesia, pertumbuhan ekonomi mencapai 5,0-5,5\% pada tahun 2010 dan Inflasi ditargetkan mencapai kisaran $5 \pm 1 \%$ pada tahun 2010. Banyaknya jumlah pengagguran di kota tangerang yang mencapai 131.643 orang atau 20,67 persen dari total pengangguran di Banten.

Faktor sosial, budaya, demografi, dan lingkungan - pertumbuhan penduduk yang cukup pesat dengan banyaknya perumahan-perumahan yang dibangun memiliki pontesi yang baik bagi perkembangan sekolah taman kanak-kanak. Sesuai dengan data dari Biro Pusat Statistik, Badan Perencanaan Pembangunan Nasional, dan United Nation Population Fund jumlah penduduk dengan usia 0-4 tahun di Banten pada tahun 2005 adalah 986.1 ribu jiwa dan pada tahun 2007 adalah 1,015.7 ribu jiwa ,tahun 2009 adalah 1,061.9 ribu, dan tahun 2010 adalah 1,076.0 ribu jiwa. Proyeksi jumlah penduduk dengan usia 0-4 tahun untuk tahun 2011 adalah 1,093.4 ribu jiwa dan untuk tahun 2013 adalah 1,129.8 ribu jiwa. Selain program yang dimiliki oleh pemerintah budaya masyarakat juga memiliki pengaruh yaitu kesadaran orang tua akan pentingnya pendidikan anak pada masa prasekolah sudah sesuai dengan pendapat para ahli psikologi yaitu perkembangan anak usia dini (0-4 tahun) merupakan "the golden age" atau masa emas dalam tahap perkembangan hidup manusia. Dikatakan sebagai masa emas, karena pada masa ini tidak kurang dari 100 miliar sel otak siap untuk distimulasi agar kecerdasan seseorang dapat berkembang secara optimal di kemudian hari. TK Hanifa sebagai salah satu penyedia jasa pendidikan anak usia dini memiliki peluang untuk dapat membantu masyarakat dalam menyediakan jasa pendidikan anak usia dini. Diperlukan pendidikan akhlak dan pengenalan agama untuk menyikapi kemajuan-kemajuan itu agar meminimalisir efek negative dan memaksimalkan keuntungan positif sebagai instrumen untuk membekali anak didik menjadi pemimpin-pemimpin yang berakhlak baik. TK Hanifa selain berfokus kepada anak didik usia dini juga mengajarkan anak dalam berperilaku sesuai dengan ajaran agama dan mengajarkan akhlak yang baik bagi anak didiknya.

Faktor teknologi - adanya kemajuan teknologi yang memungkinkan masyarakat untuk mendapatkan informasi dengan cara yang lebih mudah, hal tersebut menjadikan teknologi informasi menjadi suatu kebutuhan dalam kehidupan sekarang. Perusahaan perlu menjalankan strategi yang bisa memanfaatkan peluang yang ditawarkan teknologi untuk mencapai keunggulan kompetitif yang berkesinambuangan di pasar (David, 2009) Cara yang praktis dalam memperoleh informasi khususnya melalui internet yaitu website. Pentingnya keterlibatan orang tua dalam pemantau perkembangan anak dapat difasilitasi oleh media yang memudahkan komunikasi antar guru dan orang tua murid (Johannest et al., 2010). Selain itu dengan memanfaatkan teknologi, TK Hanifa dapat meningkatkan kemampuannya dalam melakukan pemasaran dengan cara memberikan informasi melalui website. 
Faktor kompetitif - berdasarkan data dari Biro Pusat Statistik pertumbuhan Taman Kanak-Kanak di kota tangerang sangat pesat, pada tahun 1995 terdapat 142 unit TK, tahun 2000 terdapat 154 unit TK, dan pada tahun 2003 terdapat 338 unit TK di kota Tangerang. Hal tersebut menunjukkan betapa besarnya persaingan Taman Kanak-Kanak yang ada di daerah Pamulang. Kekuatan yang dimiliki oleh TK Hanifa hampir sama dengan pesaing. Pesaing TK Hanifa adalah TK Al-Azhar dan TK Az-Zahra yang memiliki fasilitas yang sama dengan TK Hanifa, serta memiliki kualitas guru yang sama, dan sudah mulai menuju ke arah taman kanak-kanak berstandar internasional. Metode pemasaran yang dilakukan pun secara umum hampir sama yaitu dengan mengikuti berbagai pameran pendidikan, dan menyebarkan brosur maupun spanduk. Beberapa pesaing TK Hanifa antara lain: (1) TK Al-Azhar, yang sudah memiliki nama yang sangat dikenal oleh masyarakat luas sebagai sebuah lembaga pendidikan yang berpengalaman. Sekolah Al-Azhar juga bekerja sama dengan medco foundation yang kemudian menjadikan kelompok bermain di Al-Azhar bernama Aviccena sedangkan taman kanak-kanak masih bernama Al-Azhar. Selain sudah berpengalaman Al-Azhar juga memiliki pemasaran yang cukup baik yaitu memiliki website yang berada di dalam bagian website medco foundation. Perbedaan TK Hanifa dan Al-Azhar adalah metode pembelajaran yang ada dan perbandingan jumlah guru dan murid yang dimiliki, serta cara pemasaran yang dilakukan; (2) untuk kelas internasional pesaingnya adalah Kharisma Bangsa (Turkish School). Bertambahnya sekolah berstandar Internasional tentu menjadi ancaman bagi TK Hanifa, sekolah yang memiliki sistem pemasaran secara langsung ataupun memiliki website pemasaran dan sumber daya yang berasal dari luar negeri yang menerapkan sistem bilingual yaitu penerapan dua bahasa dalam pembelajaran tentu maupun yang menggunakan bahasa inggris sebagai pengantar akan menjadi salah satu daya tarik bagi para orang tua untuk memilih Taman Kanak-Kanak. Kharisma Bangsa memiliki pendidikan yang dimulai dari Taman bermain, TK, SD, SMP,dan SMA. Kharisma Bangsa merupakan kerjasama Yayasan Kharisma Bangasa dan Pasiad Foundation (Turki). Pondok Cabe, Tangerang. Mereka memiliki website sebagai salah satu cara pemasaran dan memungkinkan para muridnya untuk melakukan pendaftaran online maupun mendapatkan informasi mengenai sekolah tersebut. Dari beberapa faktor yang diuraikan di atas, dapat disimpulkan kesempatan dan ancaman bagi TK Hanifa sebagai berikut (Tabel 3).

Tabel 3

Kesempatan (Opportunity) dan Ancaman (Threat)

\begin{tabular}{cl}
\hline Opportunity \\
\hline O1 & Jumlah pertambahan penduduk usia 0-4 tahun di Banten sebesar 9\% perlima \\
& tahun \\
O2 & Kebutuhan orang tua akan informasi perkembangan anak yang up-to-date \\
O3 & Meningkatnya kepedulian orang tua terhadap pendidikan prasekolah dan agama \\
O4 & Laju pertumbuhan ekonomi (LPE) Tangerang Selatan tahun 2007 sebesar 6,51\% \\
O5 & Perkembangan ilmu pengetahuan dan teknologi informasi \\
\hline Threat & \\
\hline T1 & Pertumbuhan jumlah TK di Tangerang mencapai 119,4 \% dari tahun 2000-2003 \\
T2 & Perekonomian yang tidak stabil di kota Tangerang jumlah pengangguran 20,67\% \\
& dari total pengangguran di Banten \\
T3 & Pesaing menggunakan website untuk pemasaran dan pelayanan informasi \\
T4 & Pesaing sejenis memiliki kekuatan yang hampir sama \\
T5 & Munculnya Sekolah berstandar Internasional \\
\hline
\end{tabular}

\section{Matriks Evaluasi Faktor Eksternal}

Merupakan alat perumusan strategi yang meringkas dan mengevaluasi peluang dan ancaman suatu perusahaan. Tabel 4 berikut menunjukkan matriks evaluasi faktor internal TK Hanifa. 
Tabel 4

Matriks Evaluasi Faktor Internal TK Hanifa

\begin{tabular}{|c|c|c|c|c|}
\hline & Opportunities & Bobot & Rank & $\begin{array}{l}\text { Skor } \\
\text { Bobot }\end{array}$ \\
\hline O1 & $\begin{array}{l}\text { Jumlah pertambahan penduduk usia 0-4 tahun di Banten } \\
\text { sebesar } 9 \% \text { perlima tahun }\end{array}$ & 0,0941 & 2 & 0,1882 \\
\hline $\mathrm{O} 2$ & $\begin{array}{l}\text { Kebutuhan orang tua akan informasi perkembangan anak } \\
\text { yang } \\
\text { up-to-date }\end{array}$ & 0,0866 & 4 & 0,3464 \\
\hline $\mathrm{O} 3$ & $\begin{array}{l}\text { Perkembangan ilmu pengetahuan dan teknologi } \\
\text { informasi }\end{array}$ & 0,1288 & 4 & 0,5152 \\
\hline $\mathrm{O} 4$ & $\begin{array}{l}\text { Laju pertumbuhan ekonomi (LPE) Tangerang Selatan } \\
\text { tahun } 2007 \text { sebesar } 6,51 \%\end{array}$ & 0,0760 & 1 & 0,0760 \\
\hline O5 & $\begin{array}{l}\text { Meningkatnya kepedulian orang tua terhadap pendidikan } \\
\text { prasekolah dan agama } \\
\text { Threats }\end{array}$ & 0,0892 & 2 & 0,1784 \\
\hline $\mathrm{T} 1$ & $\begin{array}{l}\text { Pertumbuhan jumlah TK di Tangerang mencapai 119,4 } \\
\text { \% dari } \\
\text { tahun 2000-2003 }\end{array}$ & 0,1343 & 4 & 0,5372 \\
\hline $\mathrm{T} 2$ & $\begin{array}{l}\text { Perekonomian yang tidak stabil di kota Tangerang } \\
\text { jumlah } \\
\text { pengangguran 20,67\% dari total pengangguran di Banten }\end{array}$ & 0,1053 & 2 & 0,2106 \\
\hline Т3 & Pesaing sejenis memiliki kekuatan yang hampir sama & 0,0909 & 3 & 0,2727 \\
\hline $\mathrm{T} 4$ & $\begin{array}{l}\text { Pesaing menggunakan website untuk pemasaran dan } \\
\text { pelayanan informasi }\end{array}$ & 0,1487 & 4 & 0,5948 \\
\hline $\mathrm{T} 5$ & Munculnya Sekolah berstandar Internasional & 0,0460 & 1 & 0,0460 \\
\hline
\end{tabular}

Skor bobot sebesar 2.9655 yang berarti berada di atas rata-rata (titik tengah 2,5) mengindiaksikan bahwa TK Hanifa mampu menarik keuntungan dari peluang eksternal dan menghindari ancaman yang menghadang.

\section{Tahap Pencocokan}

Pada tahap ini akan dihasilkan strategi-strategi alternatif yang merupakan hasil dari pencocokan peluang dan ancaman eksternal dengan kekuatan dan kelemahan internal. Pada tahap pencocokan ini akan menggunakan Matriks Kekuatan-Kelemahan-Peluang-Ancaman (SWOT) (Tabel 5) dan Matriks Internal-Eksternal (IE) (Tabel 6).

Tabel 5

Matriks SWOT

\section{Strength (S)}

(1) Memiliki lokasi yang strategis yang berada di pusat kota tangerang selatan;

(2) Memiliki tenaga pengajar yang $50 \%$ strata 1 serta berprestasi;

(3) Pendapatan karyawan meningkat $14 \%$;

(4) Menjalankan Metode pembelajaran BCCT Sepenuhnya selama 6 tahun;

\section{Weakness (W)}

(1) Tidak memiliki tingkatansekolah dasar;

(2) TK Hanifa belum memiliki standar internasional

(3) Penyediaan pelayanan informasi lambat dan terbatas;

(4) Pemasaran terbatas pada media cetak dan keikutsertaan dalam pameran;

(5) Belum tersedia aplikasi atau 


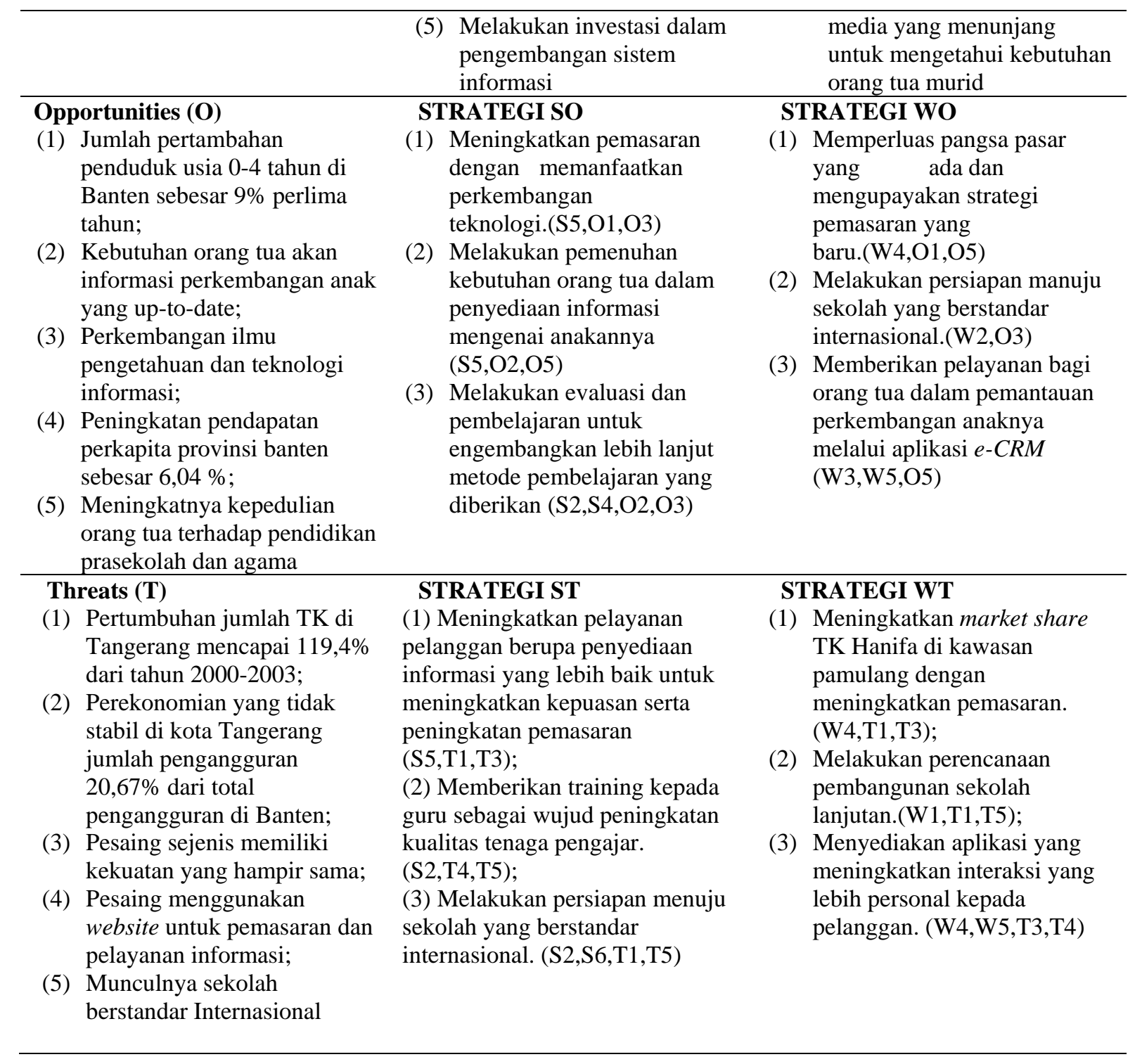

Untuk mengetahui posisi perusahaan pada saat ini digunakan Matriks internal eksternal (Matriks IE). Matriks ini menggunakan dua dimensi kunci yaitu, total IFE yang diberi pada sumbu x dan total EFE yang diberi pada sumbu y.

Tabel 6

Matriks Internal Eksternal

\begin{tabular}{|c|c|c|c|c|}
\hline \multirow{5}{*}{ 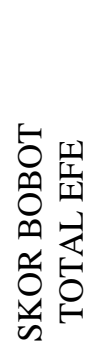 } & \multicolumn{3}{|c|}{ SKOR BOBOT TOTAL IFE } & \multirow[b]{2}{*}{$\begin{array}{c}\text { Lemah } \\
1.0-1.99\end{array}$} \\
\hline & & $\begin{array}{c}\text { Kuat } \\
3.0-4.0\end{array}$ & $\begin{array}{c}\text { Sedang } \\
2.0-2.99\end{array}$ & \\
\hline & $\begin{array}{c}\text { Tinggi } \\
3.0-4.0\end{array}$ & I & II & III \\
\hline & $\begin{array}{c}\text { SEdang } \\
2.0-2.99\end{array}$ & IV & V & VI \\
\hline & $\begin{array}{c}\text { Rendah } \\
1.0-1.99\end{array}$ & VII & VIII & IX \\
\hline
\end{tabular}


Berdasarkan Matriks IE diatas dapat diketahui berdasarkan skor bobot total IFE dan skor bobot total EFE posisi TK Hanifa berada di sel V dengan strategi Menjaga dan Mempertahankan (hold and maintain), penetrasi pasar dan pengembangan produk adalah dua strategi yang paling umum digunakan untuk sel ini.

\section{Tahap Keputusan}

Merupakan tahap akhir dari kerangka perumusan strategi dan tahapan pengambilan keputusan dari strategi alternatif yang telah dihasilkan. Pada tahap ini tim strategis akan diminta untuk memberikan peringkat atas strategi yang dihasilkan dalam skala 1 sampai 4 sehingga didapatkan strategi terbaik. Dari analisis yang dilakukan sebelumnya secara umum diperoleh dua strategi yang dapat dipertimbangkan untuk dipilih, yaitu (Tabel 7):

\section{Membangun Aplikasi E-customer Relationship management}

(1) Meningkatkan pemasaran melalui pembuatan website TK Hanifa sehingga dapat meningkatkan market share: (a) meningkatkan pemasaran dengan memanfaatkan perkembangan teknologi (S5,O1,O3); (b) memperluas pangsa pasar yang ada dan mengupayakan strategi pemasaran yang baru (W4,O1,O5); (3) meningkatkan market share TK Hanifa di kawasan pamulang dengan meningkatkan pemasaran (W4,T1,T3). Upaya peningkatan pemasaran TK Hanifa dapat memanfaatkan perkembangan teknologi, salah satunya internet, dengan membangun sebuah website. TK Hanifa diharapkan dapat meningkatkan pemasarannya dengan memberikan berbagai informasi mengenai kegiatan pembelajaran TK Hanifa metode pembelajaran yang digunakan dan fasilitas-fasilitas yang dimiliki. Upaya pemasaran ini diharapkan dapat menjangkau pasar yang lebih luas seperti kita ketahui perkembangan pengguna internet yang sangat berkembang. Hal tersebut memungkinkan TK Hanifa untuk dikenal lebih luas oleh masyarakat banyak. Pemasaran yang dilakukan tentunya diharapkan dapat memberikan dampak positif bagi perkembangan market share TK Hanifa, dimana diharapkan dapat unggul dari para pesaingnya sehingga menjadi pilihan utama para orang tua dalam memilih pendidikan prasekolah bagi anaknya.

(2) Melakukan pemenuhan kebutuhan orang tua dalam penyediaan informasi mengenai perkembangan anaknya: (a) melakukan pemenuhan kebutuhan orang tua dalam penyediaan informasi mengenai anaknya (S5,O2,O5); (b) memberikan pelayanan bagi orang tua dalam pemantauan perkembangan anaknya melalui aplikasi $e-C R M(\mathrm{~W} 3, \mathrm{~W} 5, \mathrm{O} 5)$. Dengan membangun aplikasi e-CRM diharapkan dapat memenuhi kebutuhan orang tua akan informasi anaknya yang lebih up-to-date dimana akan ada kemudahan bagi orang tua untuk memberikan laporan perkembangan anaknya dirumah. Pentingnya pemantauan perkembangan anak usia dini menjadi salah satu alasan utama kenapa aplikasi e-CRM ini dibutuhkan dimana orang tua dengan segala kesibukannya dapat tetap memantau perkembangan anaknya melalui website yang dibangun. Selain itu pihak sekolah juga dapat terbantu dengan aplikasi ini, karena dapat membuat proses pemantauan anak yang dilakukan oleh orang tua dan guru memiliki media yang memungkinkan adanya diskusi antara keduanya. Sehingga proses perkembangan anak diharapkan dapat terpantau dengan lebih baik lagi.

(3) Meningkatkan pelayanan pelanggan yang lebih baik serta meningkatkan interaksi dengan orang tua murid untuk meningkatkan kepuasan pelanggan: (a) meningkatkan pelayanan pelanggan berupa Penyediaan informasi yang lebih baik untuk meningkatkan kepuasan serta peningkatan pemasaran (S5,T1,T3); (b) menyediakan aplikasi yang meningkatkan interaksi yang lebih personal kepada pelanggan. (W4,W5,T3,T4). Hal yang paling penting dari perusahaan yang bergerak di bidang jasa atau pendidikan adalah layanan, yang diharapkan dapat menciptakan kepuasan pelanggan. Dalam pembangunan aplikasi berbasis web yaitu e-customer relationship management, selain diharapkan dapat membantu pemantauan dalam perkembangan anak juga pada akhirnya akan berupaya dalam meningkatkan kepuasan pelanggan. Aplikasi tersebut memungkinkan orang tua untuk mendapatkan 
informasi lainnya seperti materi parenting yang dilaksanakan oleh TK Hanifa dapat diakses melalui web tersebut. Selain itu informasi mengenai pembayaran serta jadwal kegiatan yang dilaksanakan juga dapat dilihat serta memungkinkan orang tua untuk memberikan kritik dan sarannya kepada TK Hanifa. Sehingga dapat tercipta interaksi yang lebih baik lagi antara orang tua murid dan pihak sekolah, diharapkan TK Hanifa dapat memahami dan berusaha memenuhi apa yang menjadi harapan dan keinginan dari konsumennya.

\section{Memfokuskan pada Pengembangan ke Pendidikan Tingkat Lanjut dan Standar Internasional}

(1) Melakukan persiapan manuju sekolah yang berstandar internasional: (a) melakukan persiapan menuju sekolah yang berstandar internasional (W2,O3); (b) melakukan persiapan menuju sekolah yang berstandar internasional (S2,S6,T1,T5). Sesuai dengan amanat UU No 20/2003 tentang Sistem Pendidikan Nasional (Sisdiknas) Direktur Pembinaan TK-SD Ditjen Dikdasmen Mudjito AK mengatakan, kabupaten/kotamadya nantinya harus memiliki sedikitnya satu TK-SD bertaraf internasional. Munculnya Taman Kanak-kanak yang bertaraf Internasional menjadikan TK Hanifa harus mampu memiliki kemampuan untuk bersaing dengan mereka. Hal tersebut memicu TK Hanifa untuk mengembangkan TK Hanifa menjadi TK yang bertaraf Internasional. Selain meningkatkan daya saing dari TK Hanifa dari sekolah-sekolah Internasional juga untuk mengatasi ancaman beralihnya para orang tua murid dari TK Hanifa. Untuk itu dibutuhkan strategi pengembangan yaitu menjadikan TK Hanifa menajdi TK yang bertaraf Internasional.

(2) Melakukan perencanaan pembangunan sekolah lanjutan (W1,T1,T5). Perencanaan pembangunan sekolah lanjutan merupakan strategi yang sangat dinantikan oleh banyak orang tua murid, dimana mereka menginginkan anaknya tetap dalam pengasuhan yayasan Hanifa. Hal tersebut juga akan mempengaruhi pilihan orang tua terhadap pendidikan prasekolah bagi anaknya karena banyak orang tua yang menginginkan kemudahan yang ditawarkan oleh taman kanak-kanak yang memiliki tingkatan sekolah dasar. TK Hanifa sudah mempersiapkan metode yang akan dijalankan pada sekolah dasar, lahan yang dipersiapkan juga sudah mencukupi tetapi masih memiliki berbagai hambatan yang ada dalam penyelenggaraan sekolah dasar, salah satu kendala yang terbesar adalah modal investasi untuk pembangunan sekolah dasar yang belum mencukupi.

Tabel 7

Matriks Evaluasi untuk Dua Strategi Alternatif

\begin{tabular}{|c|c|c|c|c|c|c|}
\hline \multirow{2}{*}{\multicolumn{2}{|c|}{ Faktor-faktor utama }} & \multirow[b]{2}{*}{ Bobot } & \multicolumn{2}{|c|}{$\begin{array}{c}\text { Membangun } \\
\text { aplikasi } \\
\text { e-customer } \\
\text { relationship } \\
\text { management }\end{array}$} & \multicolumn{2}{|c|}{$\begin{array}{c}\text { Membuat } \\
\text { tingkatan } \\
\text { lanjutan dan } \\
\text { standar TK } \\
\text { internasional }\end{array}$} \\
\hline & & & AS & TAS & AS & TAS \\
\hline \multicolumn{7}{|c|}{ Strength } \\
\hline S1 & $\begin{array}{l}\text { Memiliki lokasi yang strategis yang berada di } \\
\text { pusat kota tangerang selatan }\end{array}$ & 0,0497 & - & - & - & - \\
\hline S2 & $\begin{array}{l}\text { Memiliki tenaga pengajar yang } 50 \text { \% strata } 1 \\
\text { serta berprestai }\end{array}$ & 0,0757 & 1 & 0,0757 & 4 & 0,3028 \\
\hline S3 & Pendapatan karyawan meningkat $14 \%$ & 0,0246 & - & - & - & - \\
\hline S4 & $\begin{array}{l}\text { Telah menjalankan Metode pembelajaran } \\
\text { BCCT Sepenuhnya selama } 6 \text { tahun }\end{array}$ & 0,2013 & - & - & - & - \\
\hline S5 & $\begin{array}{l}\text { Telah melakukan investasi } \\
\text { dalampengembangan sistem informasi }\end{array}$ & 0,1797 & 3 & 0,5391 & 2 & 0,3594 \\
\hline \multicolumn{7}{|c|}{ Weakness } \\
\hline W1 & Tidak memiliki tingkatan sekolah dasar & 0,0333 & 1 & 0,0333 & 4 & 0.1332 \\
\hline W2 & $\begin{array}{l}\text { TK Hanifa belum memiliki standar } \\
\text { internasional }\end{array}$ & 0,0255 & 1 & 0,0255 & 4 & 0,1020 \\
\hline
\end{tabular}




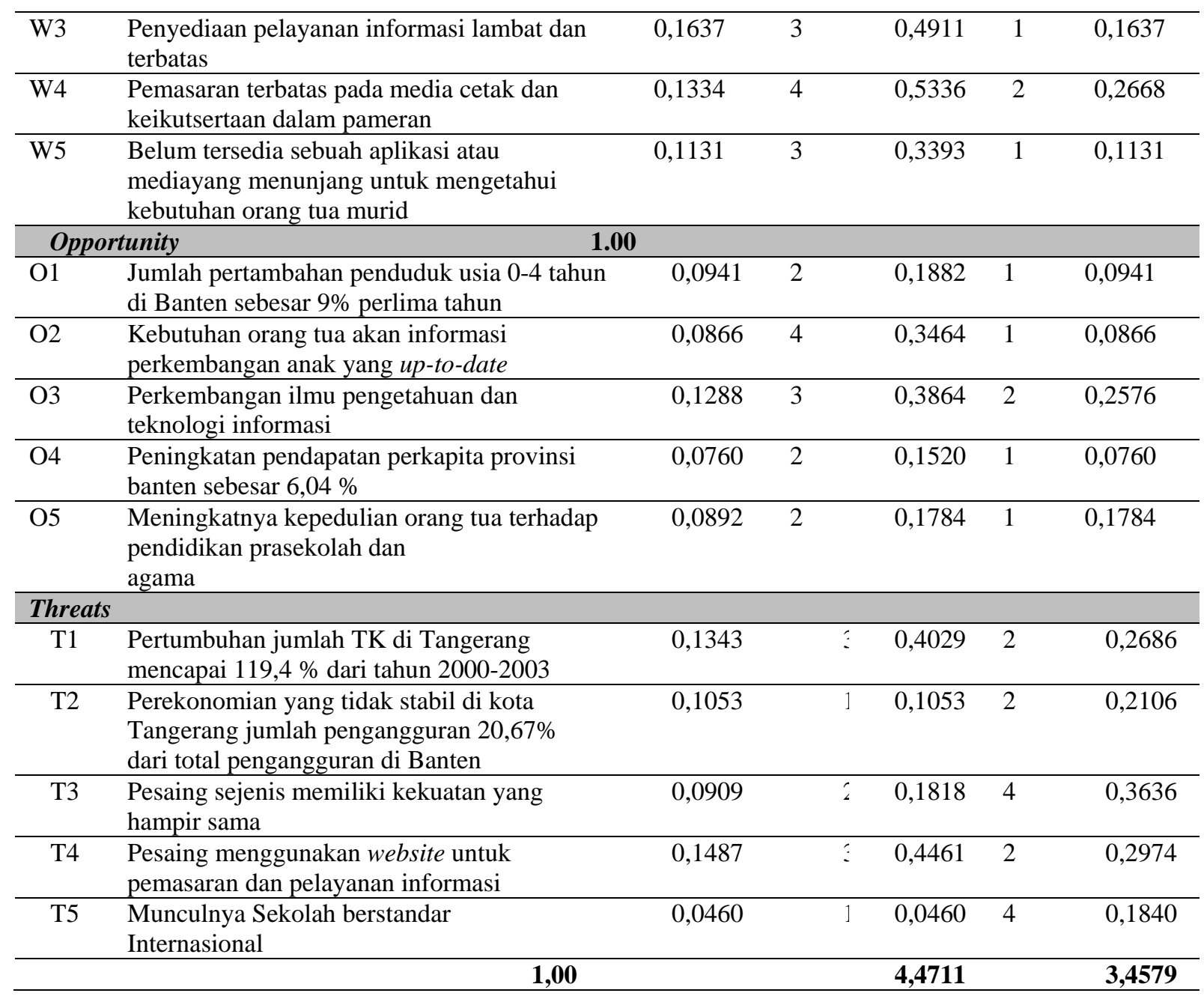

Berdasarkan perhitungan pada tabel 7 untuk dua strategi alternatif yang disusulkan bagi TK Hanifa, jumlah total daya tarik tertinggi diperoleh strategi Membangun aplikasi $e$-customer relationship management dengan jumlah total daya tarik sebesar 4,4711, dan berikutnya untuk strategi membuat tingkatan lanjutan dan standar TK internasional memiliki jumlah total sebesar 3,4579. Dengan demikian, dapat disimpulkan bahwa strategi paling baik yang dapat dijalankan oleh TK Hanifa adalah dengan membangung aplikasi e-customer relationship management.

\section{Perancangan}

Sistem Informasi yang dibutuhkan oleh TK Hanifa adalah sistem CRM terintegrasi yang berkoneksikan internet dengan tujuan meningkatkan pelayanan kepada pelanggan serta menjaga hubungan jangka panjang. Sistem ini akan dibangun sesuai dengan kebutuhan TK Hanifa dan dikembangkan untuk memberi kemudahan para orang tua murid dalam mendapatkan informasi. Fitur-fitur yang diusulkan pada perancangan sistem e-CRM ini dibuat berdasarkan analisis kebutuhan sistem melalui kuisioner yang diberikan kepada orang tua murid dan wawancara yang dilakukan kepada kepala sekolah. Berdasarkan analisis tersebut dapat diketahui permasalahan yang dihadapi serta solusi yang dapat direkomendasikan berupa fitur-fitur sebagai berikut (Tabel 8): 
Tabel 8

Usulan Fitur E-CRM Berdasarkan Kebutuhan

\begin{tabular}{|c|c|c|}
\hline Masalah & Kebutuhan & Fitur \\
\hline \multicolumn{3}{|c|}{ Fase Acquire } \\
\hline $\begin{array}{l}\text { Belum mampu melayani } \\
\text { pelanggan secara optimal } \\
\text { karena keterbatasan media dan } \\
\text { waktu operasional serta pemasaran } \\
\text { yang masih terbatas. }\end{array}$ & $\begin{array}{l}\text { Pelanggan dapat mengakses informasi yang lengkap } \\
\text { dimana saja dan kapan saja. Kebutuhan informasi } \\
\text { mengenai TK Hanifa serta jadwal kegiatan pendaftaran } \\
\text { bagi murid baru, juga pendaftaran bagi kelas } \\
\text { percobaan untuk meningkatkan pemasaran. }\end{array}$ & $\begin{array}{l}\text { Berita Tentang Kami } \\
\text { Program Registrasi } \\
\text { Hubungi Kami }\end{array}$ \\
\hline $\begin{array}{l}\text { Tidak ada media penyimpanan } \\
\text { bagi materi parenting yang } \\
\text { diadakan disekolah }\end{array}$ & $\begin{array}{l}\text { Kebutuhan akan media penyimpanan dan penyebaran } \\
\text { Informasi dari materi parenting mengenai pendidikan } \\
\text { anak usia dini, permasalahan yang dihadapi dan solusi } \\
\text { yang dapat dilakukan, serta menyediakan tempat untuk } \\
\text { memberikan komentar. }\end{array}$ & Artikel \\
\hline \multicolumn{3}{|c|}{ Fase Enchance } \\
\hline $\begin{array}{l}\text { Terbatasnya media penyampaian } \\
\text { informasi dari pihak sekolah } \\
\text { kepada orang tua murid. }\end{array}$ & $\begin{array}{l}\text { Informasi mengenai data pribadi murid dan orang tua. } \\
\text { Mengetahui informasi jadwal kegiatan dan acara } \\
\text { yang diselenggarakan di TK Hanifa serta informasi } \\
\text { laporan pembayaran murid. }\end{array}$ & $\begin{array}{l}\text { Data Pribadi } \\
\text { Jadwal Status Pembayaran }\end{array}$ \\
\hline $\begin{array}{l}\text { Informasi perkembangan anak } \\
\text { dirumah belum dimanfaatkan } \\
\text { secara maksimal }\end{array}$ & $\begin{array}{l}\text { Kebutuhan informasi berisi Laporan perkembangan } \\
\text { murid TK Hanifa terdiri dari laporan aktivitas, } \\
\text { portofolio serta rapor. Juga laporan hasil tes psikologi } \\
\text { dan kesehatan untuk pemantauan perkembangan anak. }\end{array}$ & $\begin{array}{l}\text { Laporan Perkembangan } \\
\text { Hasil Tes Psikologi } \\
\text { Laporan Kesehatan }\end{array}$ \\
\hline $\begin{array}{l}\text { Pelayanan serta interaksi antara } \\
\text { sekolah dan orang tua murid masih } \\
\text { terbatas }\end{array}$ & $\begin{array}{l}\text { Kebutuhan akan media yang memfasilitasi orang tua } \\
\text { untuk bisa melakukan interaksi dengan guru dengan } \\
\text { format diskusi yang akan dibagi menurut topik-topik } \\
\text { yang dibuat. }\end{array}$ & Forum Diskusi \\
\hline \multicolumn{3}{|c|}{ Fase Retain } \\
\hline $\begin{array}{l}\text { Terbatasnya media penyampaian } \\
\text { informasi dari pihak sekolah } \\
\text { kepada orang tua murid. }\end{array}$ & $\begin{array}{l}\text { Kebutuhan akan informasi mengenai berbagai kegiatan } \\
\text { yang dilaksanakan di TK Hanifa. Pengumuman ini } \\
\text { bersifat internal yaitu mengumumkan kegiatan TK } \\
\text { Hanifa dan orang tua murid. Orang tua murid akan } \\
\text { diberikan notifikasi mengenai pengumuman yang ada } \\
\text { di TK Hanifa melalui email. }\end{array}$ & $\begin{array}{l}\text { Pengumuman } \\
\text { Kirim News/Letter }\end{array}$ \\
\hline $\begin{array}{l}\text { Tidak terdapat sarana yang dapat } \\
\text { menampung keluhan dan saran } \\
\text { dari orang tua murid }\end{array}$ & $\begin{array}{l}\text { Kebutuhan informasi yang berisi pertanyaan - } \\
\text { pertanyaan yang sering diajukan dan jawabannya. Serta } \\
\text { menyediakan fasilitas bagi yang ingin bertanya tentang } \\
\text { TK Hanifa. }\end{array}$ & FAQ \\
\hline
\end{tabular}

Gambar $1-4$ berikut ini adalah beberapa rancangan antarmuka yang dibuat untuk website e-CRM. 


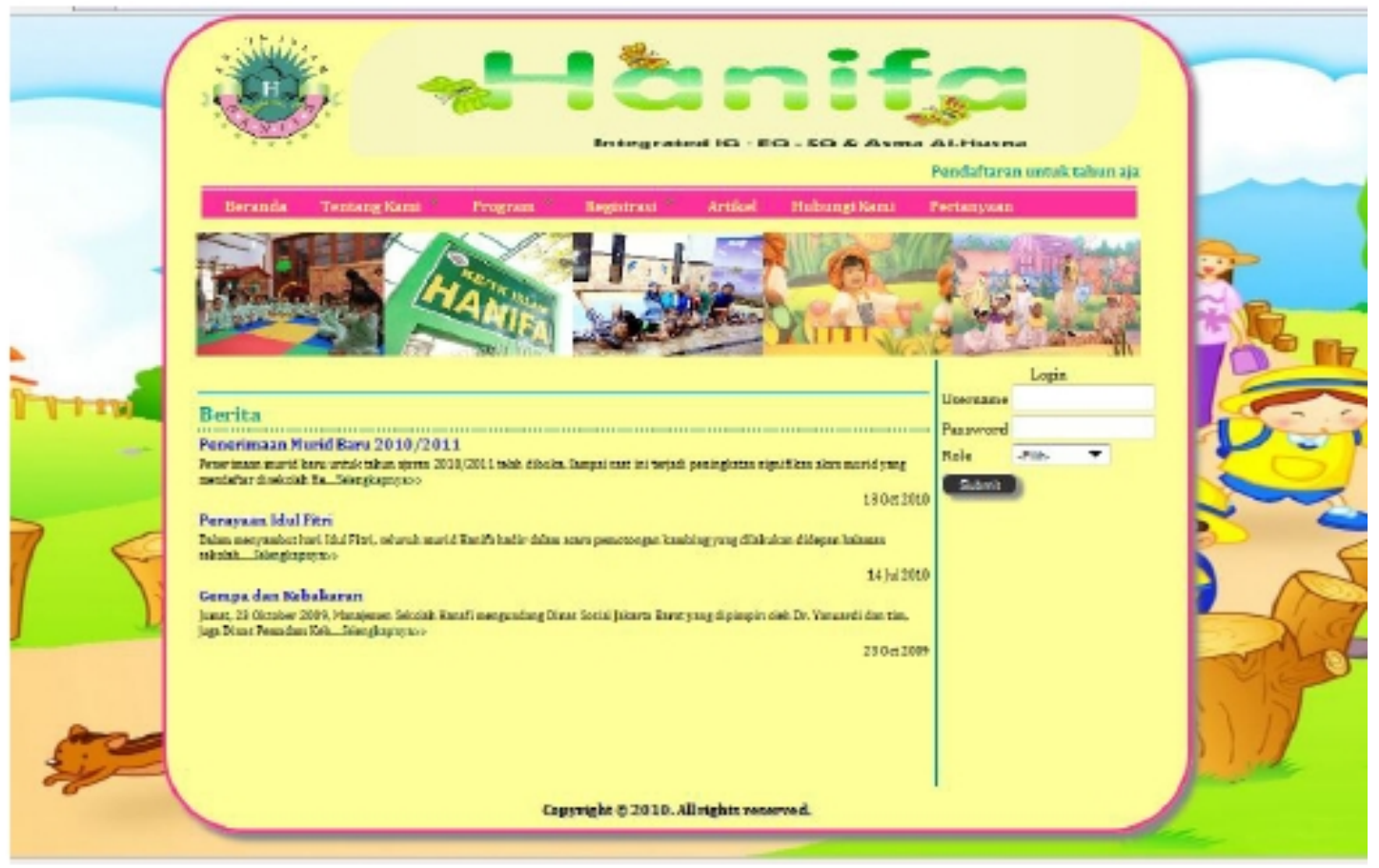

Gambar 1. Antarmuka halaman Home Publik.

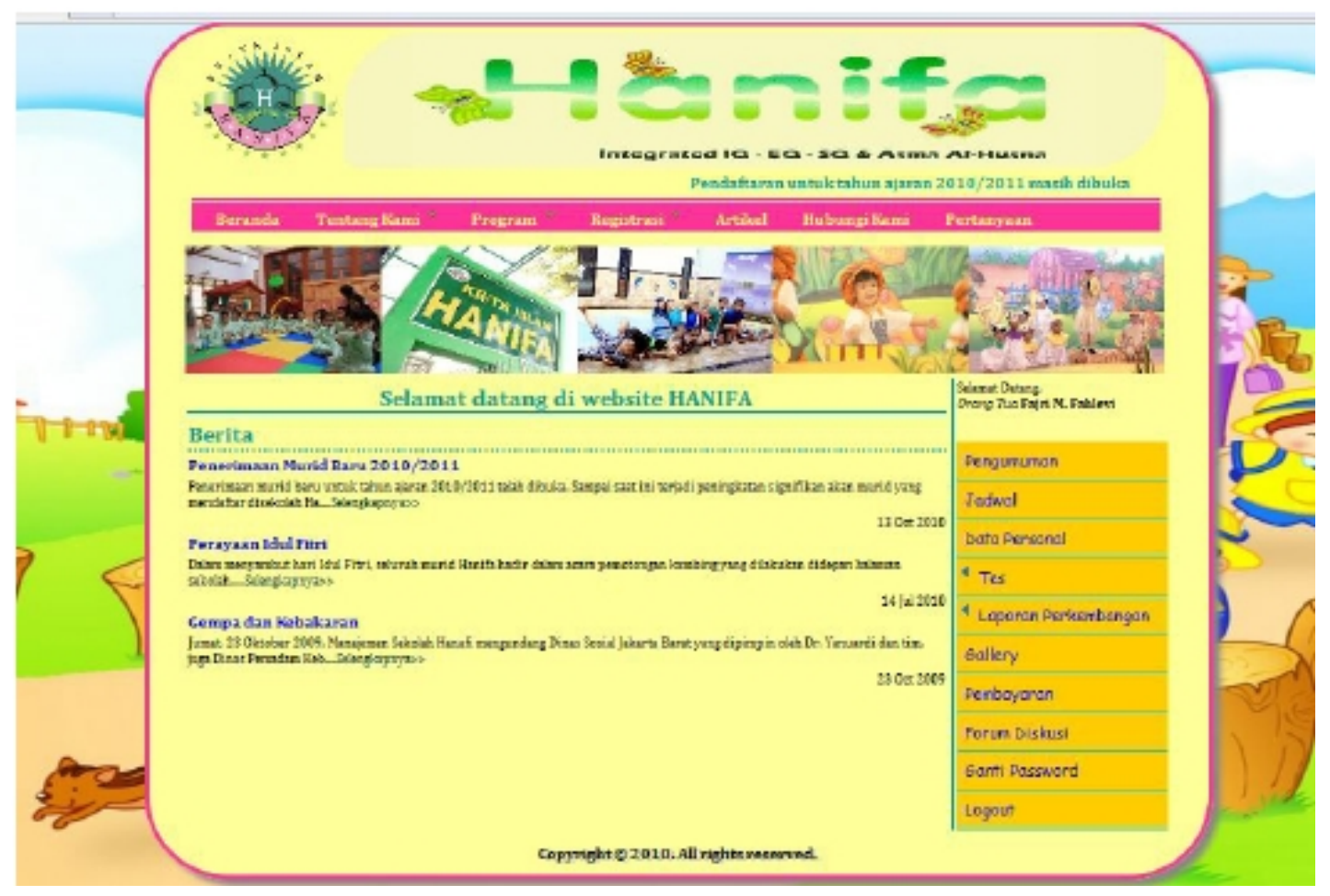

Gambar 2. Antarmuka halaman Home Orang tua 


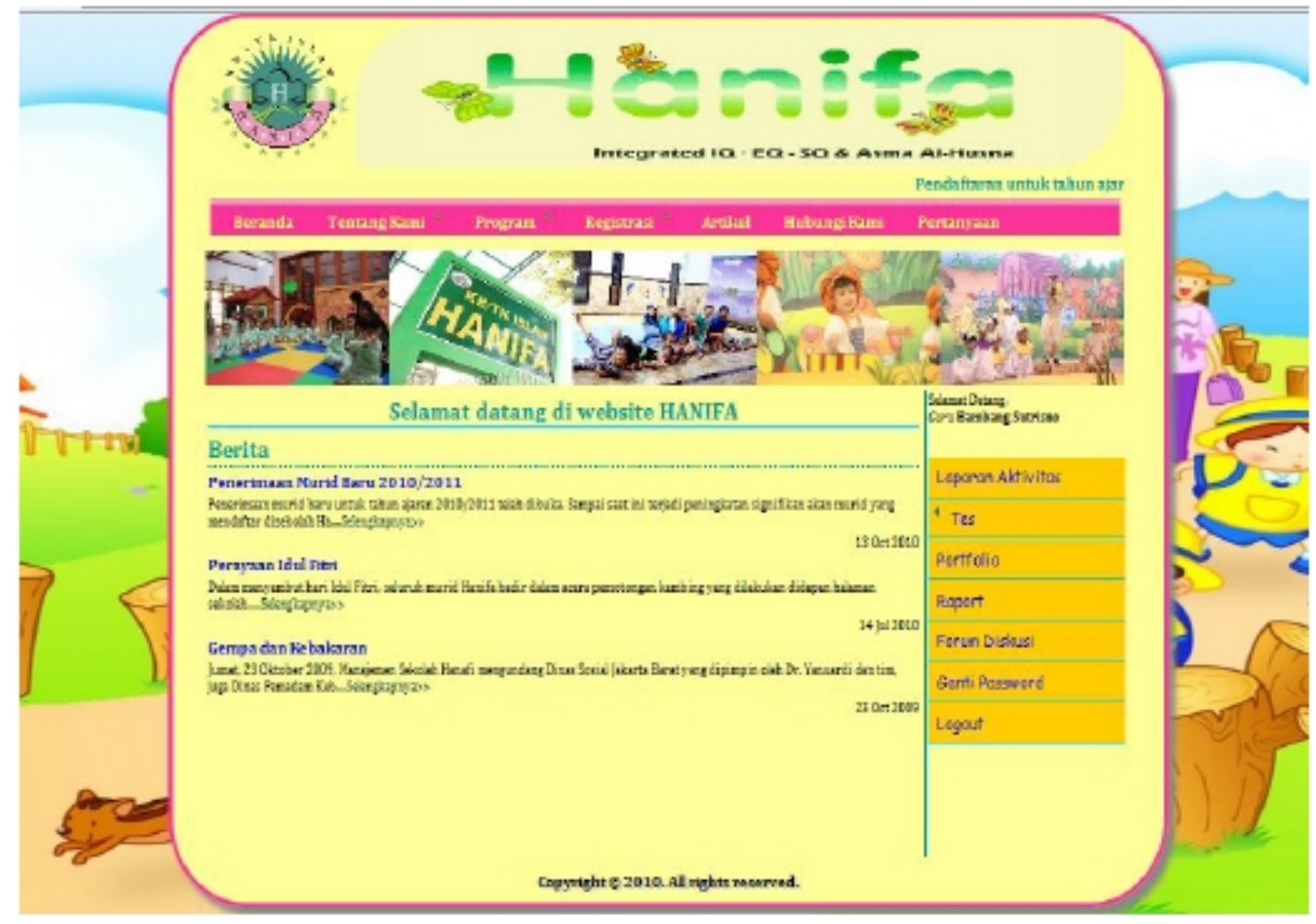

Gambar 3. Antarmuka halaman Home Guru.

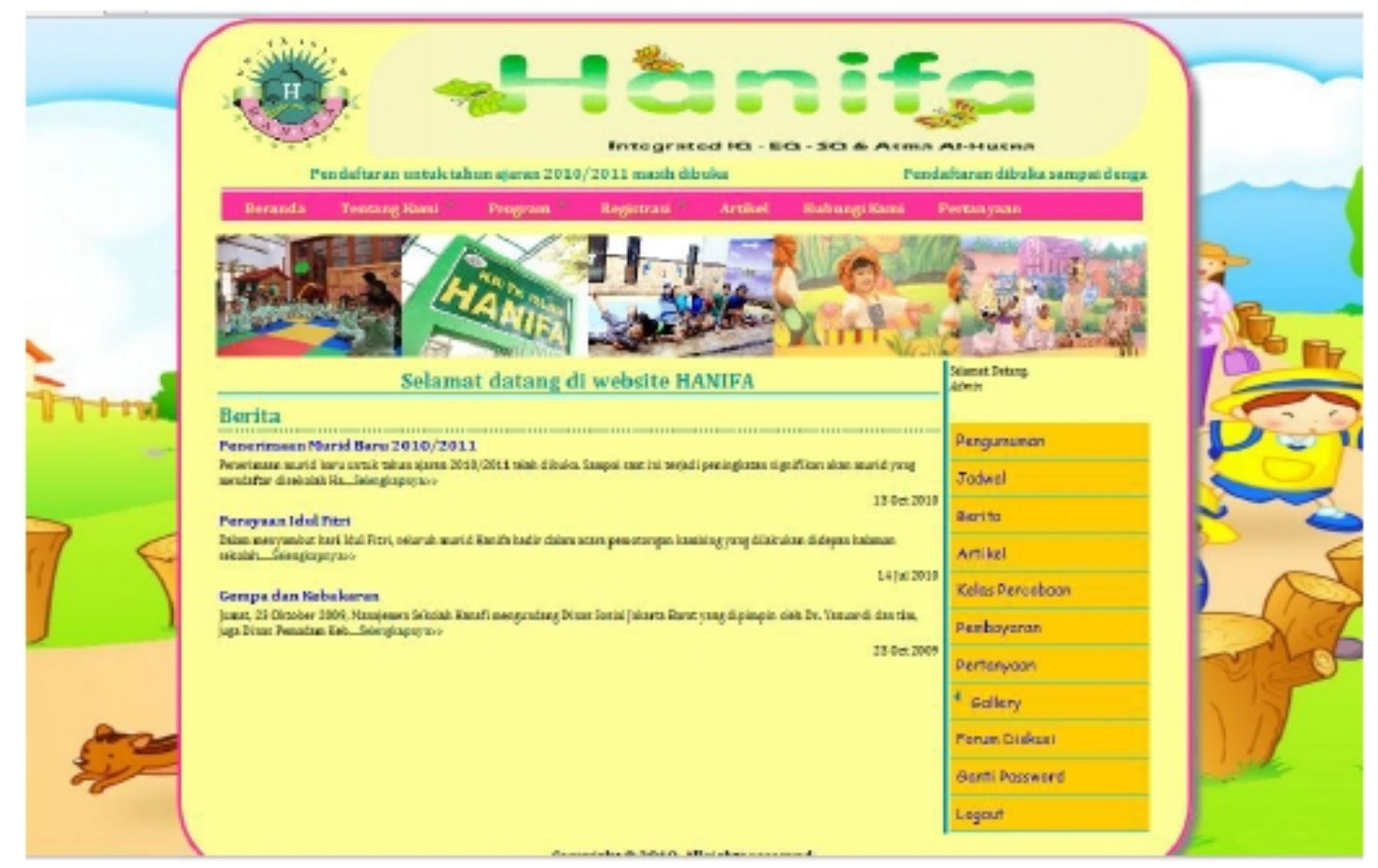

Gambar 4. Antarmuka halaman Home Admin. 


\section{PENUTUP}

Berdasarkan hasil analisis dan perancangan pada TK Hanifa yang telah dilakukan, dapat ditarik simpulan sebagai berikut: (1) perumusan strategi dengan tiga tahapan kerangka kerja menghasilkan pilihan membangun aplikasi e-CRM. Sistem e-CRM dinilai paling tepat untuk mengimplementasikan strategi yang diperoleh dari tahap sebelumnya sebagai solusi atas permasalahan yang dihadapi. Sistem e-CRM yang diusulkan akan mendukung sistem operasional yang berjalan saat ini dan mengoptimalkan interaksi sekolah dengan orang tua serta menjangkau pelanggan baru; (2) aplikasi e-customer relationship management ini dibuat untuk membantu TK Hanifa dalam meningkatkan interaksi dan pelayanan yang lebih baik untuk menjaga hubungan jangka panjang kepada orang tua murid. Untuk memberikan kemudahan orang tua dalam mendapatkan informasi dan mempermudah komunikasi dengan TK Hanifa, aplikasi ini dibuat sesuai kebutuhan Orang Tua dan TK Hanifa.

\section{DAFTAR PUSTAKA}

Baran, Roger J., Galka, Robert J., Strunk, Daniel P. (2008). Principles of Customer Relationship Management. Ohio: Thomson South-Western.

Dyche, Jill. (2002). The CRM Handbook: A Business Guide to Customer Relationship Management. Boston: Addison Wesley.

Kotler, Philip \& Keller, Kevin (2004). Marketing Management, (12th ed.). New Jersey: Prentice Hall.

Turban, E., King, D., Lee, J., Viehland, D. (2008). Electronic Commerce. New Jersey: Pearson Education. 